Voronova V, Smoliar I. Peculiarities of motivation for sports of young athletes (on the example of basketball). Theory and Methods of Physical education and sports. 2020; 1: 110-116 DOI: $10.32652 /$ tmfvs.2020.1.110-116
Воронова В, Смоляр І. Особливості мотивації до занять спортом юних спортсменів (на прикладі баскетболу) Теорія і методика фрізичного виховання і спорту. 2020; 1: 110-116 DOI: 10.32652/tmfvs.2020.1.110-116

\title{
ОСОБЛИВОСТІ МОТИВАЦІЇ ДО ЗАНЯТЬ СПОРТОМ ЮНИХ СПОРТСМЕНІВ (НА ПРИКЛАДІ БАСКЕТБОЛУ)
}

\section{Валентина Воронова, Ірина Смоляр}

Національний університет фізичного виховання і спорту України, Київ, Україна

\begin{abstract}
Анотація. Зміни, що відбуваються в суспільстві, суттєво впливають на зміст мотивів молодого покоління українців. У сучасної молоді спостерігається переоцінка колишніх цінностей і життєвих орієнтирів, що відповідно буде спрямовувати тренерів на пошук переконливих аргументів на користь мотивування, залучення молоді до занять спортом. Саме тому необхідно систематично проводити моніторинг змін особливостей мотиваційної сфери юних спортсменів, діагностику з метою отримання знань про визначення мотивів, які спонукують їх займатися спортом протягом досить тривалого часу. Мета. Визначити особливості мотиваційної сфрери спортсменів-баскетболістів 12-15 років. Методи. Аналіз науково-методичної літератури; анкетування; методи психодіагностики; методи математичної статистики. Результати. Структура мотиваційної сфери юних спортсменів, які займаються баскетболом, досить мінлива і залежна від багатьох фракторів, серед яких варто виділити успішність діяльності спортсмена, ступінь задоволеності навчально-тренувальним процесом і психологічним кліматом у команді. Для того, щоб почати самостійно займатися спортом, спортсмену-початківцю слід пройти кілька етапів: від формування позитивного ставлення до занять спортом до стійкого бажання регулярних, самостійних занять. Таким чином, тренеру необхідно знати та використовувати як відповідний психологодіагностичний комплекс для кожного з етапів формування мотивації до занять спортом, так і відповідні методи впливу на мотивацію юних спортсменів-баскетболістів до занять фрізкультурно-спортивною діяльністю.
\end{abstract}

Ключові слова: мотив, потреби, мотиваційна сфера, мотивація спортивної діяльності.

\section{Valentyna Voronova, Iryna Smoliar \\ PECULIARITIES OF MOTIVATION FOR SPORTS OF YOUNG ATHLETES (ON THE EXAMPLE OF BASKETBALL)}

\begin{abstract}
Changes in society significantly affect the content of the motives of the young generation of Ukrainians. In modern youth there is a reassessment of former values and life guidelines, which will accordingly direct coaches to find convincing arguments in favor of motivation, involvement of young people in sports. That is why it is necessary to systematically monitor changes in the characteristics of the motivational sphere of young athletes, diagnostics in order to gain knowledge about determining the motives that motivate them to engage in sports for a long time. Objective. Identify the features of the motivational sphere of basketball players aged 12-15. Methods. Analysis of scientific and methodological literature; questionnaires; methods of psychodiagnostics; methods of mathematical statistics. Results. The structure of the motivational sphere of young athletes engaged in basketball is quite variable and depends on many factors, including the success of the athlete, the degree of satisfaction with the training process and the psychological climate in the team. In order to start playing sports on their own, a novice athlete should go through several stages: from the formation of a positive attitude to sports to a strong desire for regular, independent training. Thus, the coach needs to know and use both the appropriate psychological and diagnostic complex for each of the stages of formation of motivation to play sports, and appropriate methods of influencing the motivation of young basketball players to engage in physical culture and sports activities.

Keywords: motive, needs, motivational sphere, motivation of sports activity.
\end{abstract}

Вступ. Формування стійкої мотивації до занять спортом є провідним напрямом, який визначає стійкий інтерес до занять спортивною діяльністю, пошуку шляхів підвищення спортивної майстерності, а тому залишається актуальною проблемою від самого початку занять спортом юним спортсменом і до завершення спортивної кар'єри.

Проблема мотивації й мотивів поведінки - одна зі стрижневих у психології та педагогіці спорту. Дана проблема постійно залишається в полі зору провідних науковців сфери психології та теорії спортивної підготовки, оскільки тут існує безліч невирішених питань, відповідно вона не одноразово піднімалася у великій кількості робіт вітчизняних та зарубіжних учених $[8,12,19]$. Значна кількість літератури з питань мотивації й мотивів свідчить про різноманіття точок зору як у психології, так і в інших науках [3-6, 13, 17, 21, 23].

Не менш актуальною проблемою є також підвищення якості фізкультурно-спортивної діяль- 
ності. Знання провідних мотивів дозволяє активізувати діяльність юних спортсменів, зокрема в баскетболі та підвищити їі ефективність. Однак швидкі, різнобічні і значні зміни, що відбуваються в суспільстві, суттево впливають на зміст мотивів молодого покоління українців, коли у сучасної молоді спостерігається переоцінка колишніх цінностей і життєвих орієнтирів. Нині, через певні причини, види спорту розподілилися на престижні, популярні, які приносять матеріальні здобутки, куди батьки і діти прагнуть потрапити, i традиційні, наприклад баскетбол, волейбол, велоспорт, деякі види легкої атлетики тощо, де постійно відчувається недобір у групи, що призводить до пошуку тренерами переконливих аргументів на користь мотивування, залучення молоді до занять цими видами спорту. Особливо важливою і складною проблема формування мотивації вважається у юнаків 15-17 років [17].

Саме тому необхідно систематично проводити моніторинг змін особливостей мотиваційної сфери юних спортсменів, діагностику з метою отримання знань про визначення мотивів, які спонукають їх займатися спортивною діяльністю досить тривалий час.

Роботу виконано в рамках науково-дослідної теми «Технології психолого-педагогічного супроводу та розвитку суб'єктів спортивної діяльності» на 2016-2020 pp. (номер держреєстрації 0116U001627).

Мета дослідження - визначити особливості мотиваційної сфери спортсменів-баскетболістів 1215 років.

Методи дослідження: аналіз науково-методичної літератури; анкетування; констатуючий експеримент із застосуванням методів психодіагностики для визначення мотивації відвідування спортивних занять; вивчення рівня спортивної мотивації, потреби в досягненні; оцінки рис особистості, вивчення мотивації, спрямованої на досягнення успіху та уникнення невдач; методи математичної статистики.

Результати дослідження та їх обговорення. Дослідження проходили в ДЮСШ м. Борисполя у период чемпіонату Київської області (юнацька баскетбольна ліга). У дослідженні взяли участь 24 спортсмени, 12-15 років, стаж занять $2-5$ років.

Перше застосування терміна «мотивація» належить А. Шопенгауеру [4] і з часом це поняття міцно увійшло у психологічне використання для пояснення причин поведінки людини, зокрема в спортивній діяльності. Науковці підкреслюють, що відсутність заходів із цілеспрямованого формування мотивації у спортсмена, без врахування знань соціального статусу, емоційної структури, його ставлення до певних ситуацій тощо унеможливлює та затрудняє зростання ефективності процесу навчання та тренування [9].

На сьогодні мотивація як психічне явище трактується по-різному: як сукупність необхідних чин- ників, що спрямовують і визначають поведінку (К. Мадсен; Ж. Годфруа); як сукупність мотивів (К. К. Платонов); як спонукання, що викликає активність організму й визначає їі спрямованість [20].

Така складність мотивації диктує необхідність вивчення її змісту, оскільки чим більше знає тренер про формування професійно значущої мотивації спортсменів, починаючи з початкових етапів оволодіння спортивною майстерністю, тим успішнішим та довготривалим буде перебування спортсмена в спорті. Ця необхідність спонукала психологів до детального розгляду складових мотивації спортивної діяльності, яких виділяють три [18]: психофізіологічні особливості спортсмена, його вольова сфера та рівень домагань.

Наявність психофізіологічних властивостей особистості спортсмена має важливе значення, проте, як зазначається, ще не дає підстави стверджувати, що спортсмен обов'язково досягне значних успіхів в обраному виді спорту [17]. Важливими для встановлення альтернативної мотивації, як такої, що дає спортсмену можливість здійснити конкретний вибір, є його вольові якості, де конкретно підкреслюється значення вольового зусилля (під час м'язових зусиль, концентрації уваги, подоланні втоми, відчуттів болю, небезпеки, тощо) [17]. Рівень домагань та самооцінка, які є індивідуальними у кожного спортсмена, також сприяють функціонуванню альтернативної мотивації, оскільки передбачають свідомий вибір дій, доцільних саме для досягнення успіху.

Баскетбол - гра за певними, суворо встановленими правилами. Сама техніка правил - комплекс спеціальних прийомів, необхідних баскетболістові для успішної участі у змаганнях з метою досягнення найкращих результатів командою. Та й процес навчання баскетболу (як і всіх спортивних ігор) $€$ складнішим порівняно з навчанням інших видів фізичних вправ. Юним баскетболістам необхідно вивчати не будь-який окремий рух чи дію, а цілий комплекс багатоструктурних компонентів ігрової діяльності. При цьому, як підкреслюють спеціалісти, недостатньо лише вивчити ігрові дії, необхідно вміти раціонально використовувати їх у постійно змінюваних умовах гри [16].

На початковій стадії занять спортом у дітей мотивація в основному «розмита» та характеризується розбіжністю інтересів до різних його видів. Внаслідок цього діти починають займатися одним видом спорту, потім, через короткий час переходять в інший, тобто «шукають себе», визначають свою схильність і здатності методом «проб і помилок». При цьому вони прагнуть одержати результат якнайшвидше, не розуміючи, що шлях до нього довгий та складний.

Суттєвим є те, що багато хто зі спортсменівпочатківців не можуть актуалізувати у своїй свідомості конкретний мотив вибору певного виду спорту. Але ще гірше, що ці мотиви не знають тренери. 
Згідно з дослідженнями Н. Л. Ільїної, у більшості випадків вважається, що дитина стала займатися спортом тому, що її запросив тренер [5, 22]. Глибинні причини того, чому діти прагнуть займатися саме цим видом спорту й чому багато хто з них незабаром залишають спортивні секції, залишаються тренерам невідомими.

Вивчаючи чинники, що впливають на відсів учнів з дитячо-юнацьких спортивних шкіл, науковці дійшли висновку, що тільки протягом першого року занять він досягає 80 \%, а отже не складається колектив, у спортсменів виникає розчарування спортом, проте залишається прагнення бути серед інших та зайняти певне місце в групі [1, 4, 5, 22]. Тобто, одна з головних соціальних потреб, що спрямовує процес соціалізації та керує поведінкою дітей в цьому віці, не задовольняється і вони йдуть у пошуках інших команд, пошуках відповідної спільної діяльності.

На першому році занять основними причинами відсіву є відсутність стійкого інтересу до обраного виду спорту й недоліки в методиці навчання й виховання (наприклад, участь у змаганнях непідготовлених спортсменів). На другому році сприяють відсіву невідповідність віку й розряду під час класифікаційних змагань, форсована підготовка найбільш здібних учнів («натаскування»), часта участь у змаганнях, які стають самоціллю, а не засобом удосконалення майстерності; на третьому році - невміння поєднувати заняття спортом 3 навчанням у школі, на четвертому - відсутність бажаних результатів, коли спортсмен переконується, що для занять даним видом спорту в нього бракує здібностей [4].

Ю. Ф. Курамшин виявив місце різних мотивів дітей у спорті під час відсіву [17]. Менше за все діти залишали спортивну секцію при мотивах: прагну бути схожим на знаменитого спортсмена (в обраному виді спорту), подобається даний вид спорту. Інші мотиви приходу в секцію (запросив тренер, прагну стати майстром спорту, чемпіоном світу, прагну бути здоровим, сильним, спритним тощо) не забезпечували стійкість мотиву занять даним видом спорту.

Важливе місце в підтриманні мотивації до занять спортом поступово починають відігравати стосунки із тренером. При складних позитивних стосунках спортсменів другого-третього розрядів мотив, пов'язаний з відповідальністю перед тренером, є одним 3 провідних [11].

Серед усіх мотивів занять спортом саме рівень потреби в досягненнях є визначальним в успішності і тривалості спортивної кар'єри кваліфікованого спортсмена.

Оцінювання потреби в досягненні у 12-15-річних баскетболістів проводили за шкалою оцінки потреби в досягненні успіху [10]. Ключем до розуміння сутності цієї методики є положення, що людина, у якої виражена потреба в досягненні, має тенденцію до поліпшення рівня досягнень, пере- живає успіх у діяльності, прагне завершити роботу будь-якою ціною, наполеглива у подоланні перешкод.

У ході даного дослідження встановлено, що у всіх 24 респондентів, які займаються баскетболом, найнижчий показник за даним тестом у групі становить 18 балів, а найвищий 36 балів, отже відповідає високим значенням за шкалою оцінки потреби. Встановлений рівень дозволяє стверджувати, що юні спортсмени мають високу потребу в досягненні (показник потреби досягнення більший 17 балів відповідає високому ступеню вимірюваної властивості).

На основі визначення потреби досягнення юних баскетболістів у всієї групи респондентів було виявлено показник $x=27,8 \pm 6,27$ бала, що в цілому вказує на виражену високу їх потребу в досягненні. Тобто всі вони мають високу готовність до подолання труднощів і наполегливі в подоланні складних ситуацій.

У результаті проведення діагностики мотивації відвідування спортивних занять у підлітків стало можливим визначити їхні провідні мотиви. Так, 3 24 юних спортсменів, які займаються баскетболом, в 14 осіб на першому місці переважає мотив виявити себе в спорті, це становить 58,33 \% загальної кількості респондентів, які взяли участь у дослідженні. На другому місці (8 дітей), знаходиться бажання розвинути свої фізичні якості (33,33%). Третє місце, за даними дослідження, належить мотиву добре ставлення до тренера (2 спортсмени 8,33 \%). Цікавим є те, що такі мотиви, як спілкування з друзями, престиж, вимога батьків, у даної групи баскетболістів були відсутні.

Наступним етапом нашої роботи було вивчення мотивації спортивної діяльності в юних баскетболістів, що дало можливість визначити частоту переживань ними конкретних мотивів у спорті.

Встановлено (рис. 1), що в юних спортсменів у процесі занять баскетболом на першому місці опиняється мотив боротьби й суперництва $x=25 \pm 2,59$ бала. На другому, з незначною різницею, - досягнення мети - $x=24,5 \pm 2,43$ бала; на третьому - самовдосконалення $-x=21,91 \pm 3,44$ бала, на четвертому знаходиться мотив спілкування $-x=21,25 \pm 1,65$ бала.

Отримані результати дозволяють стверджувати, що в даної групи випробуваних переважає мотив боротьби й суперництва, а також мотивація досягнення мети, а другорядними є мотиви самовдосконалення й спілкування, що в цьому віці може спричинити викривлення напряму шляхів формування пізнавальних та соціальних потреб особисті спортсмена. Беззаперечною є необхідність концентрації уваги тренерів на належному розвитку саме мотивів самовдосконалення й спілкування, що сприятиме не тільки особистісному удосконаленню спортсмена, але й зростанню ефективності, успішності його діяльності. 


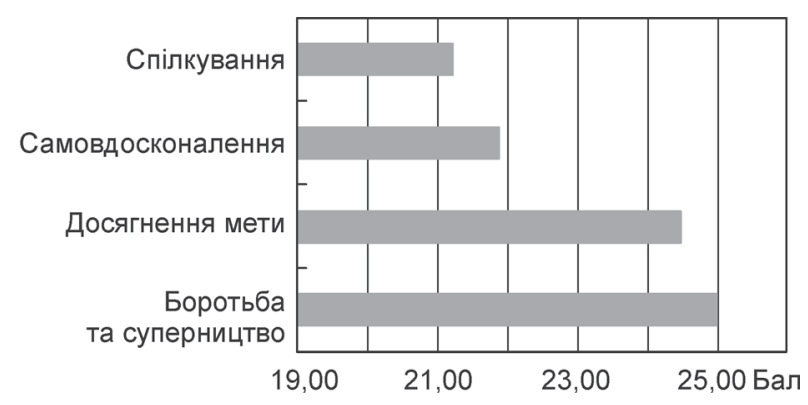

Рисунок 1 - Провідні мотиви у спортсменів-баскетболістів 12-15 років

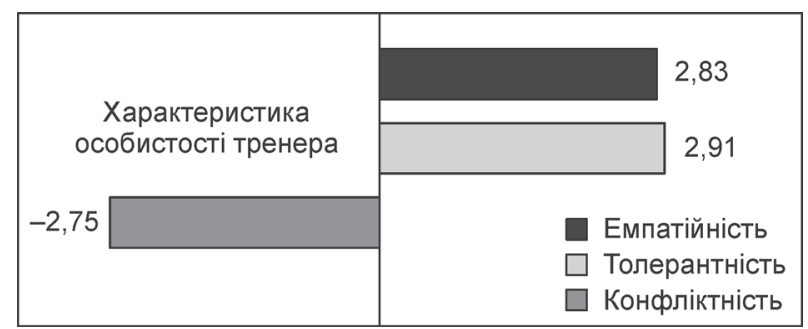

Рисунок 2 - Сприйняття спортсменами особистісних рис тренера в процесі взаємодії під час спортивної діяльності, бал

Процес дослідження дозволив встановити, що рівень мотивації до занять спортом (за адаптованою методикою Н. Г. Лусканової) перебуває у юних спортсменів на рівні вищому за середній (що є достатнім ступенем вираженості) і становить $x=17,75 \pm 3,22$ бала. Разом 3 тим, тільки у 8 з 24 респондентів (33,5\%) виявлено високий рівень, у 10 юних гравців (41,5\%) середній рівень; 6 спортсменів (25\%) мали низький рівень мотивації до занять спортом.

Наведені дані свідчать, що у 25 \% юних спортсменів зафіксовано недостатній рівень мотивації до занять спортом, що потребує швидкого реагування з боку тренера, спрямованого на підвищення стійкого інтересу та усвідомленого переконання переваг занять баскетболом; ще 41,5 \% спортсменів потребують періодичного контролю за рівнем їх мотивації, яка у них має нестійкий характер.

У ході вивчення рівня мотивації прагнення до успіху юних спортсменів виявлено на рівні $x=17 \pm 5,6$ бала, що відповідає помірковано високому рівню. Результати дослідження діагностики мотивації уникнення невдач встановили показник $x=12,9 \pm 4,6$ бала, що відповідає середньому рівню мотивації уникнення невдачі. Отримані дані дають підставу стверджувати, що юні спортсмени більше орієнтовані на успіх, ніж на уникнення невдачі або поведінку захисту, що є позитивним фактором для їх професійного вдосконалення та основою для майбутньої успішної спортивної діяльності (табл. 1).
Нами встановлено, що особливістю мотивації дітей 12-15 років, які займаються баскетболом, була наявність невеликої кількості мотивів, які є провідними відносно постійних занять спортом. Так, ними виділено такі рушійні мотиви: прагнення проявити себе в спорті й розвинути свої фізичні якості, тоді як мотиви спілкування із друзями, престиж, вимога батьків у даної групи баскетболістів були відсутні; до рідко наведених належить мотив гарне ставлення тренера. Останнє підштовхнуло нас до завдання визначення рівня вираженості професійно значущих рис особистості тренера з точки зору спортсмена: емпатії, толерантності й конфліктності в умовах тренувального процесу та взаємозв'язок рис тренера та мотивації ним спортсменів до занять спортом.

Отримані результати показали, що рівень конфліктності тренера в сприйнятті його підопічними перебуває на низькому рівні $-x=2,75 \pm 0,45$ бала, що свідчить про відсутність прояву конфліктності тренера в навчально-виховному процесі у взаємодії з підопічними на момент проведення дослідження (рис. 2).

Рівень толерантності у тренера в результаті опитування його учнів становив $x=2,91 \pm 0,28$ бала, що вказує на високий ступінь виразності даної риси у спортивного педагога. Рівень емпатійності в тренера, згідно з результатами опитування, дорівнював $x=2,83 \pm 0,38$ бала, що свідчить про високу цінність для юних учнів даної характеристики тренера як педагога під час взаємодії з ними.

Взаємозалежність між сприйняттям спортсменами рис особистості тренера i рівня мотивації до занять спортом вказуе на існування значущого прямопропорційного зв'язку ( $\mathrm{r}=0,70 ; \mathrm{p}<0,05)$ 3 низькою конфліктністю тренера й оцінкою рівня мотивації до занять у спортсменів, а також значущого прямого зв'язку $(\mathrm{r}=0,68$; $\mathrm{p}<0,05)$ емпатії тренера й рівня мотивації до занять його учнів. Тобто, у сприйнятті спортсменів $12-15$ років такі риси особистості тренера, як низька конфліктність і виражена емпатія є безумовно привабливими у взаємодії з ним і сприятимуть підвищенню мотивації до регулярних занять баскетболом у його учнів.

Таблиця 1 - Рівень мотивації до успіху та уникнення невдачі у юних баскетболістів $(\mathrm{n}=24)$

\begin{tabular}{|c|c|c|c|c|}
\hline $\begin{array}{c}\text { Рівень мотивації, } \\
\text { бал }\end{array}$ & $\begin{array}{c}\text { Рівень } \\
\text { мотивації } \\
\text { до успіху }\end{array}$ & $\%$ & $\begin{array}{l}\text { Рівень мотива- } \\
\text { ції на уникнення } \\
\text { невдачі }\end{array}$ & $\%$ \\
\hline Низький - до 10 & 2 & 15 & 4 & 30 \\
\hline Середній - 11-16 & 5 & 45 & 5 & 45 \\
\hline $\begin{array}{l}\text { Помірковано ви- } \\
\text { сокий - 17-20 }\end{array}$ & 2 & 15 & 3 & 25 \\
\hline $\begin{array}{l}\text { Занадто висо- } \\
\text { кий }-21 \text { і вище }\end{array}$ & 3 & 25 & 0 & 0 \\
\hline
\end{tabular}


Таким чином, юні спортсмени відмітили професійно значущі характеристики тренера, а саме: низьку конфліктність і високу толерантність і емпатію, що позитивно позначається на взаємодії в системі «тренер-спортсмен» i, як наслідок, на бажанні й мотивації займатися спортом.

Дискусія. На думку А. Л. Попова, основою мотивів особистості найчастіше є соціально значущий досвід, який залучає юного спортсмена до можливостей прояву фізичної активності, корекції психічних або фізичних вад, спілкування із групою однолітків, пізнання своїх можливостей, опанування «популярного» виду спорту [15]. Характерною рисою мотивації цього періоду є незначна усвідомленість потреб, що лежать в основі цих мотивів, велика різноманітність і нестійкість способів їх задоволення, а також готовність до їх швидкої зміни [4]. По суті, усі мотиви цієї стадії спрямовані на визначення того, чи є спортивне тренування необхідним й бажаним для даної особи.

Дослідники, що вивчали сутність зазначених мотивів, розподілили їх на дві узагальнені групи: спортивно-ділові (переважно це бажання досягти певних результатів, почуття суспільної відповідальності, активна позиція члена спортивної команди тощо) та особистісно-престижні (особистісне самоствердження через спорт, страх поразки, бажання виділиться 3 оточуючих тощо) [17].

Аналіз проблеми мотивації дітей до занять спортом указав на необхідність зусиль тренерів у формуванні стійких мотивів до занять спортом на початковій стадії спортивної підготовки, оскільки в цей період основними особливостями мотивації є недостатня усвідомленість потреб, нестійкість, невизначеність і взаємозамінність різних способів їх задоволення [2, 3, 9, 17, 18]. За численними свідченнями тренерів, саме в цей період спостерігається найбільша кількість випадків припинення дітьми регулярних тренувань через відсутність відповідної мотивації. Це вказує на визначальну необхідність приділення особливої уваги тренерів до формування мотивації занять спортом у дітей саме на початковому етапі підготовки.
Як зазначають провідні фахівці, важливою й однією з основних проблем під час формування мотивацій занять спортом у дітей підліткового віку є відсутність бажання й особистих переконань у необхідності цього [14]. Для того, щоб почати самостійно займатися спортом, спортсмену-початківцю слід пройти кілька етапів [20]:

- формування позитивного ставлення до занять;

- формування бажання самостійно займатися;

- здійснення цього наміру;

- перетворення цього бажання в регулярні й самостійні заняття спортом.

Для досягнення такої мети тренеру необхідно знати та використовувати як відповідний психологічно-діагностичний комплекс для кожного з етапів, так і відповідні методи корекції або впливу на мотивацію юних спортсменів-баскетболістів до занять фізкультурно-спортивною діяльністю.

Таким чином, теоретичний аналіз емпіричних досліджень дозволив встановити, що основними мотивами занять спортом у дітей 12-15 років є: боротьба та суперництво, досягнення мети, самовдосконалення та спілкування із друзями; гарне ставлення до тренера; домінуюча мотивація до успіху над мотивацією невдачі; престижність; потреба в досягненні; бажання виявити себе у спорті; розвинути свої фізичні якості.

Висновки. Мотивація фізкультурно-спортивної діяльності визначається як внутрішніми, так і зовнішніми чинниками, що змінюють своє значення протягом занять спортом. Структура мотиваційної сфери юних спортсменів, які займаються баскетболом, досить мінлива і залежна від багатьох факторів, серед яких: успішність діяльності спортсмена, ступінь задоволеності навчально-тренувальним процесом і психологічним кліматом у команді.

Перспективи подалыших досліджень спрямовані на вирішення завдань, пов'язаних з систематизацію мотивів юних баскетболістів та пошуком адекватних методів впливу на формування стійкої мотивації до занять спортом.

Конфлікт інтересів. Автори заявляють, що відсутній будь-який конфлікт інтересів.

\section{Література}

1. Волков ЛМ. Теория и методика детского и юношеского спорта: учеб. для студ. вузов фриз. культуры и фак. фриз. воспитания. Киев: Олимпийская лит.; 2002. 294 с.

2. Волкова ИП, редактор. Спортивная психология в трудах отечественных специалистов. Санкт-Петербург: Питер; 2002. 384 с.

3. Воронова В, Спесивих О. Особливості потребово-мотиваційної сфери спортсменів-танцюристів. Теорія і методика фрізичного виховання і спорту. 2013; 3: 87-90. DOI: https://doi.org/10.32652/tmfvs.2013.3.87-90

4. Ильин ЕП. Мотивация и мотивы. Санкт-Петербург: Питер; 2002. 512 с.

5. Ильина НЛ. Реализация спортсменом двойной (параллельной) карьеры. В: Гришина НВ, Шаболтас АВ, редакторы. Ананьевские чтения-2016. Материалы науч. конф.; 2016 Окт. 25-27; СПб.СПб:СПбГУ; 2016. 196-7.

6. Леонтьев ДА. Понятие мотива у А. Н. Леонтьева и проблема качества мотивации. Вестник Московского университета. 2016; 2: 3-18. (Психологія; 14). 
7. Малкин ВР, Рогалева ЛН. Психотехнологии в спорте. Екатеринбург: Изд-во Урал. ун-та; 2013. 96 с.

8. Маслоу А. Мотивация и личность. Санкт-Петербург: Евразия, 1999. 478 с.

9. Мельник ЕВ, Сивицкий ВГ, Воскресенская ЕВ. Формирование потребностно-мотивационной сферы личности спортсменов. Минск : БГУФК, 2016. 57 с.

10. Методика Орлова ЮМ. Тест-опросник: Потребность в достижения цели. Шкала оценки потребности в достижении успеха [Интернет]. Доступно: https://psycabi.net/testy. $25-8$.

11. Палайма ЮЮ. Мотивы спортивной деятельности. Теория и практика фиизческой культуры. 1966; 8:

12. Панок В, Титаренко Т, Чевелєва Н, Рибалко В, Мащенко В, Кісарук В та ін. Основи практичної психології. 3-тє вид. Київ: Либідь; 2006. 536 с.

13. Пилоян РА. Мотивация спортивной деятельности. Москва; 1984. 112 с.

14. Пономарчук ВА. Трансформации мотиваций как основа социально-психологического отбора в спорте.

В: Социальные трансформации. Материалы междунар. коллоквиума. Смоленск; 2002. Вып. 2; 103-11.

15. Попов АЛ. Спортивная психология: учебное пособие для спортивных вузов. Москва; 2000. 152 с.

16. Портных ЮИ, редактор. Спортивные игры и методика преподавания: учебник для пед. фракультетов институтов фиизиеской культуры. 2-е изд., перераб. и доп. Москва: Физкультура и спорт; 1986. 320 с.

17. Родионов ВА, редактор. Психологическое сопровождение детско-юношеского спорта: учебное пособие для бакалаврата и магистратуры. 2-е изд. Москва; Юрайт. 2019. 211 с.

18. Садайгак СС. Мотивация достижений в спорте. Минск: Белполиграф. 2002. 186 с.

19. Тищенко ВО. Мотивація самореалізації в спорті. Наука і освіта. 2013; 4: 214-7.

20. Уколов АВ. Проблемы управления спортивной мотивацией. Молодой ученый. 2010;7: 330-2.

21. Уэйнберг РС, Гоулд Д. Основы психологии спорта и физической культуры: учебник для студентов, преподавателей, работников физической культуры. Киев: Олимпийская лит.; 1998. 336 с.

22. Хвацкая EЕ. Образовательная среда спортивной школы как внешний ресурс «двойной» карьеры спортсменов. В: Ресурсы конкурентоспособности спортсменов: теория и практика реализации. Сб. науч. трудов VI Всероссийской научно-практической конференции с международным участием. Краснодар, 2016: 234-7.

23. Хекхаузен Х. Мотивация и деятельность. 2-е изд. Санкт-Петербург; Москва: Питер; Смысл; 2003.860 с.

\section{Literature}

1. Volkov LM. Theory and methods of children and youth sport: textbook for students of physical culture institutions. Kiev: Olimpiyskaya literatura; 2002. 294 p.

2. Volkova IP. Sports psychology in the works of domestic specialists. St. Petersburg: Piter; 2002. 384 p.

3. Voronova V, Spesyvylh O. Features of the need-motivational sphere of sports-dancers. Teoriia i metodyka fizvykhovannia i sportu. 2013; 3: 87-90. DOI: https://doi.org/10.32652/tmfvs.2013.3.87-90

4. Ilyin EP. Motivation and motives. St. Petersburg: Piter; 2002. 512 p.

5. Ilyina NL. Realization by the athlete of a double (parallel) career. In: Grishina NV., Shaboltas AV., editors. Ananyevskiye chteniya-2016. Materialy nauchnoy konferentsiyi; 2016 Oct. 25-27; St. Petersburg:SPbSU; 2016. 196-7.

6. Leontyev DA. Leontiev's concept of motive and the problem of motivation quality. Vestnik Moskovskogo universiteta. 2016; 2: 3-18. (Psychology; 14).

7. Malkin VR, Rogaleva LN. Psychologies in sport. Ekaterinburg: Izdatelstvo Uralskogo universiteta; 2013.96 p.

8. Maslou A. Motivation and personality. St. Petersburg: Evraziya, 1999. 478 p.

9. Melnik EV, Sivitsky VG, Voskresenskaya EV. Formation of the need-motivational sphere of the personality of athletes. Minsk: BSUPC, 2016. 57 p.

10. Methodology of Orlov UM. Questionnaire: The need to achieve the goal. Scale for assessing the need to succeed [Internet]. Available: https://psycabi.net/testy.

11. Palayma YY. Sports activity motives. Teoriya i praktika fizicheskoy kultury. 1966; 8: 25-8.

12. Panok V, Tytarenko T, Chevelieva N, Rybalko V, Mashchenko V, Kisaruk V et al. Fundamentals of practical psychology. 3-rd ed. Kyiv: Lybid; 2006. 536 p.

13. Piloyan RA. Sports activity motivation. Moscow; 1984. 112 p.

14. Ponomarchuk VA. Transformations of motivations as a basis of social and psychological selection in sports. In: Social Transformations. Materialy mezhdunarodnogo kollokviuma. Smolensk; 2002. Iss. 2; 103-11.

15. Popov AL. Sports psychology: teaching guide for sports institutions. Moscow; 2000. 152 p.

16. Portnykh YI. Sports games and teaching methods: textbook for pedagogical departments of physical culture institutions. 2-nd revised edition. Moscow: Fizkultura i sport; 1986. 320 p.

17. Rodionov BA. Psychological support of children and youth sports: teaching guide. 2-nd ed. Moscow; Yurayt. 2019. $211 \mathrm{p}$.

18.Sadaygak SS. Motivation of sports achievements. Minsk: Belpoligraf. 2002. 186 p.

19. Tyshchenko VO. Self-realization motivation in sport. Nauka i osvita. 2013; 4: 214-7.

20. Ukolov AV. Problems of sports motivation management. Molodoy ucheny. 2010;7: 330-2. 
21. Weinberg Robert S, Gold Daniel. Bases of sports psychology and physical culture. Kyiv: Olimpiyska literatura, 1998. 336 p.

22. Khvatskaya EE. The educational environment of a sports school as an external resource of a «double» career of athletes. In: Resources of competitiveness of athletes: theory and practice of implementation. VI Vserosiyskaya nauchno-prakticheskaya konferentsiya. Krasnodar, 2016: 234-7.

23. Khekhausen H. Motivation and activity. 2-nd ed. St. Petersburg; Moscow: Piter; Smysl; 2003. 860 p.

\section{Інформація про авторів}

Воронова Валентина Іванівна https://orcid.org/0000-0002-5072-4184, professor.voronova@gmail.com

Смоляр Ірина Іванівна

https://orcid.org/0000-0001-8817-7035, rusiksmol@gmail.com

Національний університет

фізичного виховання і спорту України

03150, Київ, вул. Фізкультури, 1

\section{Information about the authors}

Voronova Valentyna

https://orcid.org/0000-0002-5072-4184

professor.voronova@gmail.com

Smoliar Iryna

https://orcid.org/0000-0001-8817-7035,

rusiksmol@gmail.com

National University

of Ukraine on Physical Education and Sport

03150, Kyiv, Fizkul'tury str., 1. 